\title{
PHOSPHORUS BALANCE AT TARTU WWTP, ESTONIA
}

\author{
Hillar Toomiste ${ }^{1,2}$ \\ Jüri Haller ${ }^{1}$ \\ Mait Kriipsalu ${ }^{2}$ \\ Valdo Kuusemets ${ }^{2}$ \\ 1) Tartu Waterworks Ltd, Estonia \\ 2) Estonian University of Life Sciences, Tartu
}

\begin{abstract}
Sewage sludge is usually considered as treatment residue that needs expensive treatment for removal. The treatment and handling of sludge can form 20 to $50 \%$ from a wastewater treatment facility's costs. Sludge volumes will continue to grow worldwide with increasing population and country wealth. In a sustainable society, sludge should rather be seen as a source of energy, phosphorus and other products. Water treatment facilities are exploring technologies to utilise these values worldwide. Technologies on extracting minerals from sludge would either help offset treatment facility's costs or even turn a profit. First step in turning sludge from a costly waste material into a profitable revenue stream should be a material balance.

In Tartu wastewater treatment plant $\left(120000 \mathrm{pe}, 28000 \mathrm{~m}^{3} \mathrm{~d}^{-1}\right)$ waste water is treated by activated sludge process with an integrated biological nitrogen and phosphorous removal. Sludge is dewatered and stabilized by windrow composting. In the treatment plant, phosphorus balance in various treatment steps was studied and potential technologies for extracting phosphorus were reviewed.
\end{abstract}

\section{KEYWORDS}

Phosphorus removal, recovery and reuse; extraction, balance, sludge, struvite; wastewater

\section{INTRODUCTION}

\subsection{Phosphorus - a limited or abundant resource}

Phosphorus (P) is an essential macronutrient for crop production. Agriculture accounts for about $80 \%$ of the phosphate ore utilisation worldwide, which is finite and non-renewable resource. Current phosphate deposits may last for only a hundred years at the present depletion rate [1]. Phosphorus may become a limiting substance in the future and phosphorus leakage from existing sludge deposits may become a diffusive phosphorus source. The excess content of phosphorus in receiving waters leads to intensive algae and hydrophyte growth, known as eutrophication. 
Biological phosphate removal in activated sludge processes was reported in seventies [2-4], and currently it is a common phosphorus removal step in most modern treatment plants. However, as phosphorus concentrations in effluent water decrease, phosphorus concentrations in waste activated sludge (WAS) increase. Increased phosphorus concentrations in WAS lead to two significant problems commonly faced by plant operators: undesirably high levels of phosphorus in sludge intended for land application, and struvite clogging during anaerobic treatment $[5,6]$.

Sewage sludge is usually considered as treatment residues, which is expensive to get rid of. The treatment and handling of sludge can represent between 20 and $50 \%$ of a wastewater treatment facility's costs. Sludge production volumes will continue to grow worldwide with increasing population and country wealth. In a sustainable society, sludge should rather be seen as a source of energy, phosphorus and other products. Water treatment facilities are exploring technologies to extract these values worldwide. Technologies on extracting minerals from sludge would either help offset treatment facilities costs or even turn a profit.

\subsection{Extraction of $P$, review}

There are currently several alternative ways to remove phosphorus from wastewater enabling its recovery and reuse as fertilizer [7]:

-improved sludge quality at treatment plants and use of the sludge for agricultural purposes,

- improved wastewater treatment systems using reactive filter media,

- processing of the sludge into separate fractions to obtain phosphorus containing products with a high purity,

- processing of sludge incineration ashes to obtain phosphorus containing products,

- phosphorous crystallisation in the effluent process flow,

- combined precipitation of phosphorous and nitrogen in the wastewater,

- phosphorous adsorption on activated clay,

- ion exchange in the effluent process flow,

- acid P-extraction and precipitation.

\section{Direct application of sludge compost}

Biological removal of phosphorus generates large amounts of sludge, which is costly to manage and does not always allow efficient phosphorus recovery. Sludge compost has been preferred instead of liquid application. Sludge drying, pelletizing or briquetting has been practiced to achieve more hygienic application, and slower release of nutrients.

\section{Filter substrates}

There is a large variety of reactive porous filter substrates, rich in $\mathrm{Ca}, \mathrm{Fe}$ or $\mathrm{Al}$ with a high affinity for $\mathrm{P}[8-10]$. The mechanisms of $\mathrm{P}$ retention involve sorption processes at the surface of the material. Once saturated with $\mathrm{P}$ the material could be recycled back to agriculture. $\mathrm{P}$ in the material should be in a form capable of desorbing and being released to the soil $\mathrm{P}$ solution, thus becoming available to plants [8].

\section{Formation of Struvite}

Phosphorus recovery through struvite $\left(\mathrm{MgNH}_{4} \mathrm{PO}_{4} \times 6 \mathrm{H}_{2} \mathrm{O}\right)$ crystallization and the possible reuse of struvite as a fertilizer is widely reported [5, 11-14]. Safe and quick extraction of high purity calcium phosphate, magnesium phosphate or Struvite pellets has been studied by many authors. The formation of magnesium phosphates such as $\mathrm{MgHPO}_{4} \times 3 \mathrm{H}_{2} \mathrm{O}$ (newberyite), 
$\mathrm{Mg}_{3}\left(\mathrm{PO}_{4}\right)_{2} \times 8 \mathrm{H}_{2} \mathrm{O}$ (bobierrite) and $\mathrm{Mg}_{3}\left(\mathrm{PO}_{4}\right)_{2} \times 22 \mathrm{H}_{2} \mathrm{O}$ (cattiite), during struvite crystallization or dissolution process, is reported already in early works [15] as well as late ones [16]. A complete phosphorus removal and recovery from anaerobically digested sludge liquors as struvite has been implemented in Japan, and the resulting product sold to fertiliser companies $[17,18]$. Struvite can be used as slow release fertilizer at high application rates, without the danger of damaging plant roots. Granular forms of struvite are one of the best, slow release phosphorus fertilizers $[17,19]$.

\section{Microwave extraction}

Phosphorus in sludge can be released into solution by heating it to 50 to $70^{\circ} \mathrm{C}$ prior to anaerobic digestion with microwave irradiation [6]. Domestic and industrial microwave ovens generally operate at a frequency of $2.45 \mathrm{GHz}$ corresponding to a wavelength of $12.2 \mathrm{~cm}$ and energy of $1.02 \times 10^{-5} \mathrm{eV}$ [20]. Unlike anaerobic processes, the phosphorus released consists of a significant fraction of phosphorus that is not orthophosphate. Likely mechanisms for release include cell membrane disruption, causing the release of stored polyphosphate into solution, and the release of phosphorus trapped in extracellular polymeric material. Microwave irradiation also causes the release of arsenic, molybdenum, nickel, and selenium into solution [6], which is a problem in case they are present in wastewater.

\section{Solvent extraction}

Inorganic phosphorus can be extracted and separated from municipal wastewater with primary amine as a solvent in the presence of sodium molybdate [23].

\section{Phosphorus recovery from sludge ash}

Phosphorus recovery from sludge ash has been studied [21]. After the thermo-chemical treatment at $1000^{\circ} \mathrm{C}$, a mechanical finish transforms the clean phosphate semi-product to marketable phosphate and complex fertilizers. Direct phosphorus recovery from sludge incineration ash by leaching with acid or base has been shows, that acid leaching allows to recover phosphorus as iron phosphate, which, however, has low commercial value [22].

\subsection{Phosphorus balance in treatment plant}

First step in turning phosphorus-rich liquids or sludge from a costly material to treat into a profitable revenue stream should be a material balance. In Tartu Wastewater Treatment Plant (WWTP), phosphorus balance in various treatment steps was studied, aiming to find potential technologies for extracting phosphorus.

\section{MATERIAL AND METHODS}

\subsection{Tartu treatment plant}

Tartu WWTP is serving Tartu town and adjacent regions nearby Tartu with the capability of 120000 pe and $28000 \mathrm{~m}^{3} \mathrm{~d}^{-1}$ [24]. According to the current process, the technological concept of the WWTP is activated sludge treatment with nitrogen removal according to the modified Ludzack Ettinger (MLE) concept, and integrated biological phosphorous and nitrogen removal according to $\mathrm{A} 2 / \mathrm{O}$ process. In addition to the biological phosphorous removal, chemical phosphorous removal with iron(III)sulphate is integrated. The chemical 
precipitate is mixed into the organic excess sludge. Sludge is dewatered, and stabilized by windrow composting. The working parameters are in Table 1.

Table 1. The efficiency of the Tartu WWTP

\begin{tabular}{lcccc}
\hline & \multicolumn{2}{c}{ Influent $\mathrm{mg} \mathrm{L}^{-1}$} & \multicolumn{2}{c}{ Effluent $\mathrm{mg} \mathrm{L}^{-1}$} \\
& Planned & Actual & Limit value [25] & Actual \\
\hline Biochemical Oxygen Demand, BOD & 257 & $120-300$ & 15 & $4-10$ \\
Chemical Oxygen Demand, COD & 510 & $180-1200$ & 125 & $25-55$ \\
Suspended Ssolids, SS & 357 & $150-650$ & 15 & $7-12$ \\
Total Phosphorus, $\mathrm{P}_{\text {tot }}$ & 10.7 & $7-15$ & 1,0 & $0.6-2.0$ \\
${\text { Total Nitrogen, } \mathrm{N}_{\text {tot }}}$ & 51 & $30-60$ & 10 & $6-17$ \\
\hline
\end{tabular}

\subsection{Sampling}

Eight sampling points were taken from the most characteristic locations of the WWTP, where high values of dissolved phosphorus were expected. The sampling points are numbered on a layout of the treatment plant, see Figure 1.

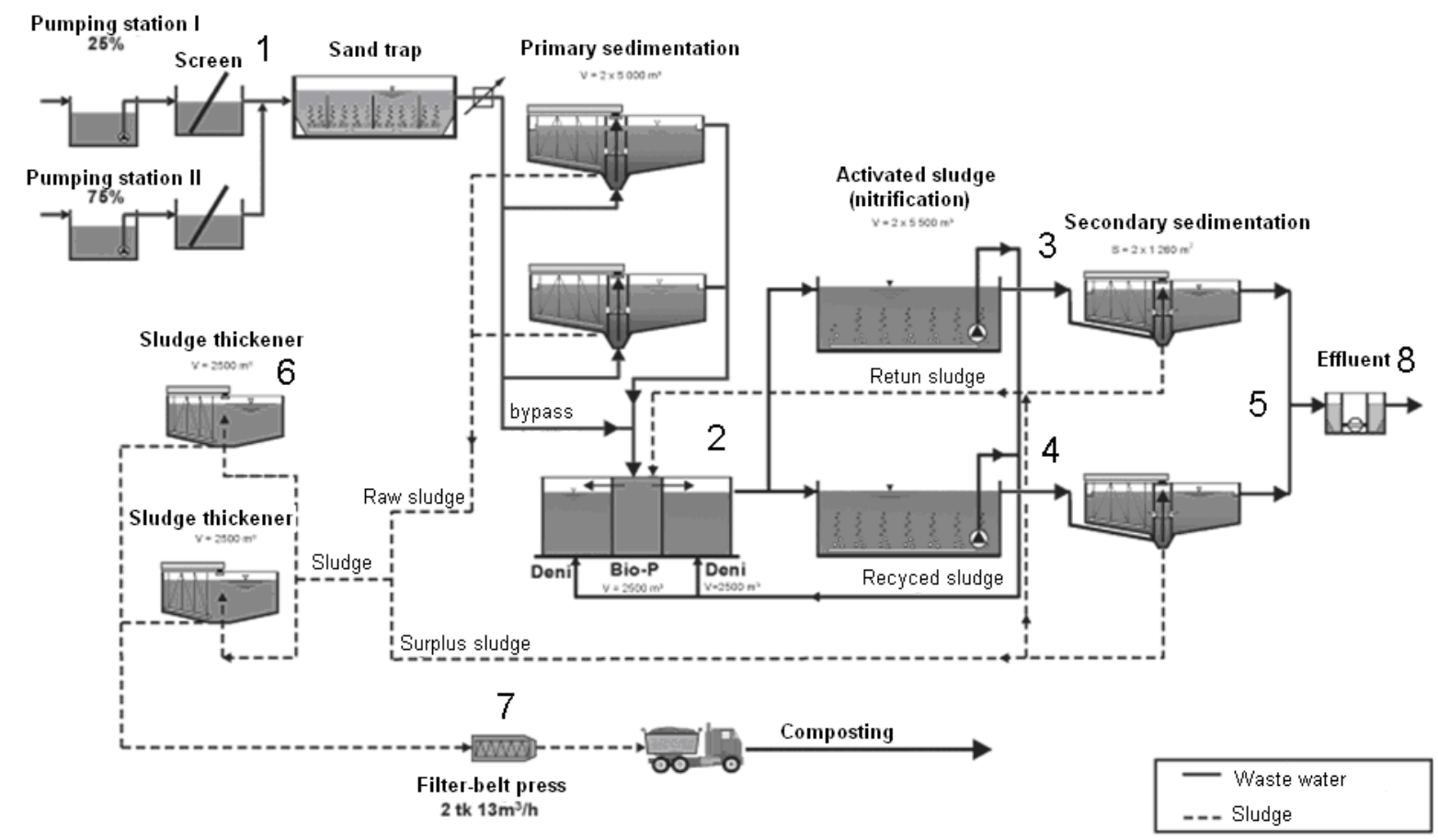

Figure 1. Location of sampling points at Tartu WWTP

\subsection{Laboratory procedures}

Total phosphorus and phosphates, as well as $\mathrm{pH}$, conductivity, and COD were analyzed at the accredited laboratory of Tartu Waterworks Ltd. All the analytical methods were recommended by EU and ISO standards, all the samples were filtered. 


\section{RESULTS AND DISCUSSION}

The results show that sludge liquor contains about $100 \mathrm{mg} / 1$ total phosphorus, most of this $(87-95 \%)$ as a dissolved phosphates. Second largest concentration of phosphorus was measured in surplus activated sludge $-41 \mathrm{mg} \mathrm{L}^{-1}$. Concentrations in influent to the WWTP were as large as concentrations from anoxic zone, designed as for P-removal - 5.68 and 5.35, respectively (Table 2).

The average hydraulic flow was $31332 \mathrm{~m}^{3} \mathrm{~d}^{-1}$ on the particular sampling days. The total phosphorous load on these days was $210 \mathrm{~kg} \mathrm{~d}^{-1}$ and the yearly average load is $300 \mathrm{~kg} \mathrm{~d}^{-1}$. The total hydraulic load is $12156669 \mathrm{~m}^{3} \mathrm{y}^{-1}$ on the year 2009 what makes phosphorous load between 82-110 t $\mathrm{y}^{-1}$. Effluent from WWTP is still consisting phosphorous $0.7-0.9 \mathrm{mg} \mathrm{L}^{-1}$ what makes $8.5-11 \mathrm{t} \mathrm{y}^{-1}$. It means that $72-100 \mathrm{t} / \mathrm{y}$ is possible range for phosphorous recovery from Tartu WWTP.

Table 2. Characteristics of the samples

\begin{tabular}{lccccc}
\hline \multicolumn{1}{c}{ Sampling point } & $\begin{array}{c}\mathrm{P}_{\text {tot }} \\
\mathrm{mg} \mathrm{L}^{-1}\end{array}$ & $\begin{array}{c}\mathrm{PO}_{4}{ }^{3-} \\
\mathrm{mg} \mathrm{L}^{-1}\end{array}$ & $\begin{array}{c}\mathrm{COD} \\
\mathrm{mgO} \mathrm{L}^{-1}\end{array}$ & $\begin{array}{c}\text { Conductivity } \\
\mathrm{mS} \mathrm{cm}^{-1}\end{array}$ & $\begin{array}{c}\mathrm{pH} \\
\mathrm{pH} \text { unit }\end{array}$ \\
\hline 1. Influent to WWTP & 5.58 & 4.24 & 214 & 1.26 & 7.77 \\
2. Effluent from anoxic area & 5.68 & 5.35 & 76 & 1.20 & 7.22 \\
3. Effluent from aeration tank no 1 & 0.28 & 0.17 & 53 & 1.13 & 7.42 \\
4. Effluent from aeration tank no 2 & 0.19 & 0.09 & 62 & 1.10 & 7.43 \\
5. Effluent from secondary & 0.73 & 0.55 & 34 & 1.14 & 7.31 \\
$\quad$ sedimentation tank & & & & & \\
6. Surplus activated sludge & 40.9 & 38.5 & 213 & 1.15 & 6.89 \\
7. Sludge liquor & 98.5 & 89.2 & 190 & 2.22 & 6.99 \\
8. Effluent from WWTP & 0.72 & 0.44 & 37 & 1.14 & 7.88 \\
\hline
\end{tabular}

\section{CONCLUSIONS}

Recovery of phosphorus for recycling, rather than its transfer into dewatered sewage sludge, may offer economic and environmental rewards for the water industry. In Tartu, Estonia, 82-110 tons of phosphorus enters into the WWTP, and 71-100 tons is removed as part of dewatered sludge. Large proportion of it could be removed from liquid phase in most phosphorous abundant sources, e.g. sludge liquor.

For the phosphate industry, extraction of nutrients holds out the promise of a significant source of sustainable raw material - phosphorus, which is comparatively free from heavy metals. These benefits must be compared with the investment and running costs of phosphorus recovery installations.

\section{ACKNOWLEDGEMENTS}

The study was funded by the by the Estonian Centre for Higher Education Development, Foundation Archimedes ESF DoRa, which is gratefully acknowledged. 


\section{REFERENCES}

[1] Steen, I., 1998. Phosphorus availability in the 21st century: Management of a nonrenewable resource. Journal of phosphorus and potassium, Issue no. 217 (Sept-Oct).

[2] Levin, G.V., Topol, G.J., Tarna A.C., Samworth R.B, 1972. Pilot plant tests of a phosphorus removal process. J. Water Pollut. Control Fed. 44 (10), 1940-1954.

[3] Barnard, J-L., 1974. Cut P and N without chemicals. Water and Waste Eng. 11(7), 33-36.

[4] Fuhs, G.W., Chen, M., 1975. Microbiological basis of phosphate removal in the activated sludge process for the treatment of wastewater. Microbial Ecol. 2, 119-138.

[5] Balmér P., Hultman B., 1988. Control of phosphorus discharges: present situation and trends. Hydrobiologia vol.170, 305-319.

[6] Danesh P., Hong, S.M., Moon, K.W., Park, J.K., 2008. Phosphorus and Heavy Metal Extraction from Wastewater Treatment Plant Sludges Using Microwaves for Generation of Exceptional Quality Biosolids. Water Environ Res. Sep; 80(9), 784-95.

[7] de-Bashan, Y., Bashan, L.E., 2004. Recent advances in removing phosphorus from wastewater and its future use as fertilizer. Water Res. 38, 4222-4246.

[8] Cucarella, V., Zaleski, T., Mazurek, R. Renman, G., 2007. Fertilizer Potential of CalciumRich Substrates Used for Phosphorus Removal from Wastewater. Polish J. of Environ. Stud. Vol. 16, No. 6, 817-822.

[9] Johansson Westholm L., 2006. Substrates for phosphorus removal - Potential benefits for on-site wastewater treatment. Water Res. 40, 23.

[10] Berg, U., Donnert, D., Ehbrecht, A., Bumiller, W., Kusche, I., Weidler, P.G., Nuesch, R., 2005. "Active filtration" for the elimination and recovery of phosphorus from wastewater. Colloids and Surfaces A: Physicochem. Eng. Aspects 265, 141.

[11] Bhuiyan, M.I.H., Mavinic, D.S., Koch F.A., 2008. Thermal decomposition of struvite and its phase transition. Chemosphere 70, 1347-1356

[12] Battistoni, P., Boccadoro, R., Fatone, F., Pavan, P., 2005. Autonucleation and crystal growth of struvite in a demonstrative fluidized bed reactor (FBR). Environ. Technol. 26, 975-982.

[13] Marti, N., Pastor, L., Bouzas, A., Ferrer, J., Seco A., 2010. Phosphorus recovery by struvite crystallization in WWTPs: Influence of the sludge treatment line operation. Water Research 44, 2371-2379.

[14] Pastor, L., Mangin, D., Ferrer, J., Seco A., 2010. Struvite formation from the supernatants of an anaerobic digestion pilot plant. Bioresource Technology 101, 118-125

[15] Taylor, A.W., Frazier, A.W., Gurney, E.L., Smith, J.P., 1963. Solubility products of di-and trimagnesium ammonium and dissociation of magnesium phosphate solutions. Trans. Farad. Soc. 59, 1585-1589.

[16] Michalowski, T., Pietrzyk, A., 2006. A thermodynamic study of struvite + water system. Talanta 68, 594-601.

[17] Gaterell, M.R., Gay, R., Wilson, R., Gochin, R.J., Lester, J.N., 2000. An economic and environmental evaluation of the opportunities for substituting phosphorus recovered from wastewater treatment works in existing UK fertilizer markets. Environ. Technol. 21, 1067-1084.

[18] Ueno, Y., Fujii, M., 2001. Three years experience of operating and selling recovered struvite from full-scale plant. Environ. Technol. 22, 1373-1381.

[19] Bridger, G.L., Salutsky, M.L., Starostka, R.W., 1962. Metal ammonium phosphates as fertilizers. J. Agr. Food Chem. 10, 181-188.

[20] Jacob, J., Chia. L.H.L., Boey, F.Y.C., 1995. Review - thermal and non-thermal interaction of microwave radiation with materials. Jour. of Materials Sci., 30(21), 5321. 
[21] Adam, C. Peplinski, B., Michaelis, M., Kley, G., Simon, F.-G., 2009. Thermochemical treatment of sewage sludge ashes for phosphorus recovery. In Waste Management 29, 1122-1128

[22] Levlin, E., Löwén M., Stark K., 2004. Phosphorus recovery from sludge incineration ash and Supercritical Water Oxidation residues with use of acids and bases. Proceedings of a Polish-Swedish seminar, Report No 11. Joint Polish-Swedish Reports, Wisla Poland, 2003.10.25-10.28. Trita.LWR Report 3004, ISBN: 91-7283-664-4, pp. 1928

[23] Zhao, Y., Lin, M., 1999. Separation of inorganic phosphorus from municipal wastewater by solvent extraction with primary amine in the presence of sodium molybdate. Chemical Speciation and Bioavailability, Vol. 11, No 4, 137-141(5)

[24] Terase, H., Haller, J., 2001. Wastewater and Leachate Treatment in Tartu Wastewater Treatment Plant. EcoTech 2001

[25] RTI 2001, 69,424 Regulation No. 269 of July 2001 of the Government of the Republic of Estonia "Requirements for Waste Water Discharged in to Water Bodies or into Soil" 